\title{
Identification and Characterization of a Functional nodD Gene in Azorhizobium caulinodans ORS571
}

\author{
KOEN GOETHALS, GUY VAN DEN EEDE, MARC VAN MONTAGU, AND MARCELLE HOLSTERS* \\ Laboratorium voor Genetica, Rijksuniversiteit Gent, B-9000 Ghent, Belgium
}

Received 30 November 1989/Accepted 6 February 1990

\begin{abstract}
Azorhizobium caulinodans ORS571, a bacterium capable of nodulating roots and stems of the tropical legume Sesbania rostrata, has been shown to have no nodD-like gene located immediately upstream from its common nodABC locus. A clone carrying a functional nodD gene of strain ORS571 has now been isolated from a pLAFR1 gene library by screening for naringenin-induced expression of the common nod genes in an Agrobacterium background. Tn5 mutagenesis of the cloned insert DNA delimited the inducing activity to a \pm 0.8 -kilobase-pair fragment. One of the Tn5 insertions in the activator locus was homogenotized in the ORS571 genome. This resulted in a mutant strain (ORS571-3) that was unable to induce common nod gene expression in the presence of host plant exudate or the flavanone naringenin and that had lost the capacity to nodulate the roots and stems of $S$. rostrata. Complementation of both mutant phenotypes was achieved upon introduction of the cloned nodD gene. Sequencing of the nodD locus indicated the presence of a single, 942-base-pair-long open reading frame (ORFD) with significant homology to the nodD genes of (brady)rhizobia. The level of homology, however, is the lowest thus far reported for this kind of gene. ORFD most likely initiates translation with a TTG start codon. Upstream from ORFD, a divergently oriented nod box-like sequence is present, the function of which remains to be determined.
\end{abstract}

The interaction between leguminous plant species and soil bacteria belonging to the genera Bradyrhizobium and Rhizobium can lead to the development of nodules on the roots of the host plant. In these new plant organs, differentiated bacteria (bacteroids) encounter favorable conditions for symbiotic nitrogen fixation. Several bacterial and plant genes involved in the establishment of this symbiosis have been studied extensively during the last few years (for reviews, see references 23 and 26 ).

More recently, Azorhizobium caulinodans ORS571 has been described as the archetypical species of a new genus of soil bacteria which, apart from being diazotrophic in freeliving conditions, is also able to nodulate effectively the tropical legume Sesbania rostrata (11). A unique feature of the host plant is the occurrence of dormant root primordia in vertical rows all along the stem. Upon infection by $A$. caulinodans, these primordia develop into $\mathrm{N}_{2}$-fixing aerial or stem nodules (9).

To understand the factors that contribute to the formation of these $\mathrm{N}_{2}$-fixing aerial nodules, we started identifying and characterizing Azorhizobium genes involved in the nodulation process. In previous reports, we described the identification and characterization of common nodABC-related genes $(14,34)$ that are essential for the interaction with the host plant and are highly conserved among rhizobia, bradyrhizobia, and, to a lesser extent, the genus Azorhizobium.

In (brady)rhizobia, the common nod genes are organized in an operon that is coregulated with other nod operons by a positive, regulatory function encoded by the nodD gene. The NodD proteins typically have a molecular mass of approximately 34 kilodaltons and are classified in the recently described LysR family of transcriptional activators (18). On the basis of sequence alignments, each member of this protein family is predicted to have an amino-terminally located helix-turn-helix motif involved in DNA binding. It

\footnotetext{
* Corresponding author.
}

has indeed been demonstrated that NodD proteins bind specifically at a particular, conserved DNA sequence (the nod box consensus) located upstream from inducible nod operons $(12,22,27)$. Activation of nod gene expression by NodD occurs only in the presence of specific (iso)flavonoidtype inducer molecules that are exuded by the host plant. Mutational and recombinational experiments suggest a direct interaction between the inducer molecules and the NodD protein $(5,19,32)$. In most cases documented, a nodD gene is linked to, but divergently transcribed from, the common nod genes. In $A$. caulinodans, common nodABCrelated genes were shown to be very likely organized in an operon, but no evidence for an upstream located nodD gene was found (14). However, the regulation of expression of the A. caulinodans common nod genes is very similar to that of the (brady)rhizobial nod operons. Using lac $Z$ fusions, it was demonstrated that the expression of ORS571 nod locus 1 genes is activated in the presence of host plant exudate or the flavanone naringenin (14). This led us to suspect that a related regulatory mechanism is present in ORS571. In this report, we present confirmation of this hypothesis by showing the existence in $A$. caulinodans of a nodD-homologous gene that is essential for plant-inducible nod gene expression as well as for nodulation of $S$. rostrata stems and roots.

\section{MATERIALS AND METHODS}

Bacterial strains, plasmids, and bacteriophages. Strains, plasmids, and phages used are listed in Table 1.

Growth media and culture conditions. Cultures of ORS571 or derivatives were grown at $37^{\circ} \mathrm{C}$ on LSR medium (34) or MMO medium (14). When necessary, antibiotics were applied in the following concentrations (micrograms per milliliter): carbenicillin, 100; tetracycline, 10; kanamycin, 20; and spectinomycin, 20.

Cultures of Agrobacterium strain GV3101 were grown at $28^{\circ} \mathrm{C}$ on YEB medium or PA medium (36). When necessary, rifampin was added to a final concentration of $100 \mu \mathrm{g} / \mathrm{ml}$, tetracycline was added to $5 \mu \mathrm{g} / \mathrm{ml}$, spectinomycin was added 
TABLE 1. Bacterial strains, phages, and plasmids

\begin{tabular}{|c|c|c|}
\hline Strain or plasmid & Relevant characteristics & Source or reference \\
\hline \multicolumn{3}{|l|}{ Strains } \\
\hline ORS571 & $\begin{array}{l}\text { A. caulinodans type strain capable of nodulating roots and stems of } S \text {. } \\
\text { rostrata }\end{array}$ & 10,11 \\
\hline ORS571-S & $\begin{array}{l}\text { Spontaneous mutant of ORS571 unable to regulate the expression of the } \\
\text { common nod genes }\end{array}$ & This work \\
\hline ORS571-3 & Tn 5 insertion mutant in the nodD regulatory gene & This work \\
\hline GV3101 & $\begin{array}{l}\text { Rif derivative of Agrobacterium tumefaciens cured of its pTiC58 plas- } \\
\text { mid }\end{array}$ & 35 \\
\hline MC1061 & 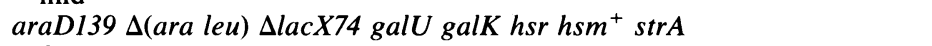 & 6 \\
\hline CSH2110 & polA $\mathrm{Nal}^{\mathrm{r}}$ & 17 \\
\hline \multicolumn{3}{|l|}{ Phages } \\
\hline M13mp8 & M13 cloning vector & 37 \\
\hline M13mp8-nodDl & $\begin{array}{l}\text { M13mp8 clone carrying a } 249-\mathrm{bp} \text { Bam HI-BglII insert containing the } 5 \text { ' } \\
\text { section of the } R \text {. meliloti nodDl gene }\end{array}$ & 16 \\
\hline \multicolumn{3}{|c|}{ 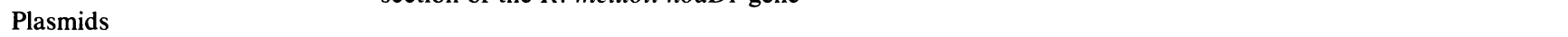 } \\
\hline pBR325 & repColE1 $\mathrm{Cb}^{\mathrm{r}} \mathrm{Tc}^{\mathrm{r}} \mathrm{Cm}^{\mathrm{r}}$ & 4 \\
\hline pRK2013 & repColE1 $\mathrm{Km}^{\mathrm{r}} \mathrm{Tra}^{+} \mathrm{mob}^{+}$used as a helper plasmid in conjugations & 8 \\
\hline pUC8 & $\mathrm{Cb}^{\mathrm{r}}$ ColE1 cloning vector & 37 \\
\hline pUC8-4 & pUC8 with a 4-kb EcoRI-BamHI subfragment carrying ORFD & This work \\
\hline pJS144 & $\begin{array}{l}\text { pACYC184 carrying a } 1.7-\mathrm{kb} \text { EcoRI fragment containing the nodD1 of } \\
\text { R. meliloti }\end{array}$ & $\begin{array}{l}\text { J. Schmidt and M. John } \\
\text { (personal communica- } \\
\text { tion) }\end{array}$ \\
\hline pBH264 & pRK290 derivative carrying the nodD gene from MPIK3030 & 19 \\
\hline pRK290 & Wide-host-range cloning vector; $\mathrm{Tc}^{\mathrm{r}} \mathrm{Tra}^{-} \mathrm{mob}^{+}$IncP & 8 \\
\hline pLAFR1 & Wide-host-range cosmid, derived from pRK290; $\mathrm{Tc}^{\mathrm{r}}$ & 13 \\
\hline pGV910 & rep pVS1 $\mathrm{Cb}^{r} \mathrm{Cm}^{\mathrm{r}} \mathrm{Sm}^{\mathrm{r}} / \mathrm{Sp}^{\mathrm{r}}$ mob ColE1 mob $\mathrm{RP} 1$ & $\begin{array}{l}\text { R. Deblaere (personal } \\
\text { communication) }\end{array}$ \\
\hline pRG910-12 & pGV910 with a $12.7-\mathrm{kb} E c o R I$ fragment carrying the ORS571 nod locus 1 & This work \\
\hline pRG290-12 & pRK290 with a $12.7-\mathrm{kb}$ EcoRI fragment carrying the ORS571 nod locus 1 & 14 \\
\hline pRG290-12::M3 & pRG290-12 containing a nodC-lacZ fusion & 14 \\
\hline pRG290-12::M21 & pRG290-12 containing a nodB-lacZ fusion & 14 \\
\hline pRG290-12::T20 & pRG290-12 containing a nodA-lac $Z$ fusion & 14 \\
\hline pRG290-12::M63 & pRG290-12 containing an ORF4-lacZ fusion & 14 \\
\hline pRG910-12::M3 & pGV910-12 containing a nodC-lacZ fusion & 14 \\
\hline pRG701::M3 & $\begin{array}{l}\text { pBR325 containing a } 12.7-\mathrm{kb} \text { EcoRI fragment carrying the ORS571 nod } \\
\text { locus } l \text { genes with lac } Z \text { fused to the nodC gene }\end{array}$ & 14 \\
\hline pRG701::M63 & $\begin{array}{l}\text { pBR325 containing a } 12.7-\mathrm{kb} \text { EcoRI fragment carrying the ORS571 nod } \\
\text { locus } 1 \text { genes with lac } Z \text { fused to ORF } 4\end{array}$ & 14 \\
\hline pRG100 & $\begin{array}{l}\text { pLAFRI clone isolated from the ORS571 gene bank carrying a functional } \\
\text { nodD gene }\end{array}$ & This work \\
\hline pRG910-16 & pGV910 containing a 16-kb EcoRI fragment of the pRG100 insert & This work \\
\hline pRG910-4 & $\begin{array}{l}\text { Subclone of pRG910-16 containing a 4-kb EcoRI-BamHI fragment carry- } \\
\text { ing the ORS571 nodD gene }\end{array}$ & This work \\
\hline pRG910-16::Tn5-3 & pRG910-16 containing a Tn5 insertion in ORFD & This work \\
\hline
\end{tabular}

to $100 \mu \mathrm{g} / \mathrm{ml}$, kanamycin was added to $25 \mu \mathrm{g} / \mathrm{ml}$, and carbenicillin was added to $100 \mu \mathrm{g} / \mathrm{ml}$.

Escherichia coli cultures were grown on LB medium (24) with the addition of antibiotics, when needed, at the following concentrations (micrograms per milliliter): tetracycline, 10; kanamycin, 25; carbenicillin, 100; streptomycin, 100; spectinomycin, 100; and nalidixin, 60 .

Molecular cloning techniques. Standard molecular biology techniques for restriction enzyme digests, cloning, electrophoresis, fragment isolation from gels, and labeling of DNA fragments were as described previously (24). In pGV910, no useful $\mathrm{BamHI}$ site is available for subcloning the 4-kilobasepair (kb) EcoRI-BamHI subfragment of pGV910-16, carrying open reading frame D (ORFD). Therefore, a HindIII site was generated immediately next to the BamHI site of this 4-kb fragment by subcloning in pUC8 and digestion of the resulting clone (pUC8-4) with EcoRI-HindIII. Cloning of this fragment in EcoRI-HindIII-cut pGV910 resulted in the recombinant plasmid pGV910-4.

DNA sequence determination and analysis. A 1.1-kb DNA fragment of the pUC8-4 insert was sequenced, using $M \& G$ paper to bind DNA according to a modified Maxam-Gilbert sequencing procedure of Amersham (U.K.). Compilation and analysis of the sequence data was done by using the IntelliGenetics suite version 5.3 software for SUN.

DNA hybridizations. ORS571 total DNA preparation, labeling of double-stranded DNA probes, and DNA hybridizations were done as described previously (34). M13mp8derived, single-stranded DNA was labeled by using the New England BioLabs sequencing primer 1211 and DNA polymerase I Klenow fragment as described by New England BioLabs.

When single-stranded DNA of phage M13mp8-nodDI (harboring a 249-nucleotide fragment of the amino-terminal part of Rhizobium meliloti nodD1; Table 1) was used as a hybridization probe against EcoRI-digested ORS571 total DNA, a large number of ORS571 fragments were found to hybridize. However, a similar pattern of homology was observed when labeled M13 DNA (without a nodD insert) was used as probe. This is reminiscent of observations described in literature where sequences in the M13 gene III 
were shown to hybridize under low-stringency conditions to eucaryotic as well as to bacterial DNA fragments $(20,28)$.

Triparental matings. Matings were done for ORS571 as well as for Agrobacterium sp. by using the helper plasmid pRK2013 (8).

In vivo construction of pRG910-12::M3. Plasmid pRG701::M3 was transformed into the polA $E$. coli derivative CSH2110(pRG910-12). Since pRG701::M3 is a ColE1derived replicon, it cannot be maintained in a polA strain but it can be rescued by cointegration via homologous recombination with the pRG910-12 insert. Cointegrates were screened for segregation of the pBR325 marker $\mathrm{Tc}^{\mathrm{r}}$ and maintenance of the M3 (Mu dIIPR13) insertion marker $\mathrm{Cm}^{\mathrm{r}}$. The plasmid DNA of several putative double recombinants (pRG910-12::Mu3) was analyzed by restriction enzyme digest to verify the structure.

Tn5 insertion mutagenesis of pRG910-16. The Tn5 insertions in the clone pRG910-16 were isolated in E. coli MC1061 by the $\lambda:: \operatorname{Tn} 5$ mutagenesis method (7).

Isolation of an ORFD::Tn5 homogenote. The 22-kb EcoRI insert from pRG910-16::Tn5-3 was cloned in pBR325. The resulting plasmid, pBR325-16::Tn5-3, was introduced into wild-type ORS571 by triparental mating.

From $\mathrm{Tc}^{\mathrm{r}} \mathrm{Km}^{\mathrm{r}}$ transconjugants harboring a cointegrate, $\mathrm{Km}^{\mathrm{r}} \mathrm{Tc}^{\mathrm{s}}$ derivatives were isolated after replica plating on medium with and without tetracycline. Total DNA of putative homogenotes was isolated, cut with EcoRI, and hybridized to a pBR325-16::Tn5-3 probe to verify their true structure.

$\beta$-Galactosidase assays. Quantitative $\beta$-galactosidase assays (using $o$-nitrophenyl- $\beta$-D-galactoside [ONPG] as a substrate) and screening of induced $\beta$-galactosidase expression on MacConkey agar (Difco Laboratories) plates were carried out as described previously (25). In vivo plate assays in the presence of $S$. rostrata plantlets or explants were performed as described before (14).

Nodulation tests. Nodulation tests were done as described previously (34).

Chemicals. $X$-Gal (5-bromo-4-chloro-3-indolyl- $\beta$-D-galactoside) was purchased from Research Organics Inc., and ONPG was purchased from J. T. Baker Chemicals N.V. Naringenin was purchased from CarlRoth $\mathrm{GmbH}+\mathrm{Co}$.

\section{RESULTS}

Failure to find a nodD-related ORS571 gene by DNA hybridization studies. Since the expression pattern of the ORS571 common nod genes is very similar to that of the (brady)rhizobial nod operons, we thought it very likely that strain ORS571 could harbor one or more nodD-related genes. In a first attempt to identify such genes, we carried out hybridization experiments of EcoRI-digested total ORS571 DNA with well-characterized nodD clones (or subfragments) as probes. The same low-stringency hybridization conditions that had allowed us previously to detect a nodC-related ORS571 gene (34) were used. When the purified insert fragment of pJS144, carrying the $R$. meliloti nodDl gene, or the pBH264 insert fragment, carrying nodDI from strain MPIK3030 (Table 1), was used as a hybridization probe, no homology to ORS571 DNA could be detected (see Materials and Methods). Therefore, if nodD-related sequences are present in ORS571, we calculated them (according to reference 1) to be more than $44 \%$ divergent in nucleotide sequence as compared with the probes used.

Identification of a cloned ORS571 DNA fragment involved in naringenin-induced expression of ORS571 nod genes in an

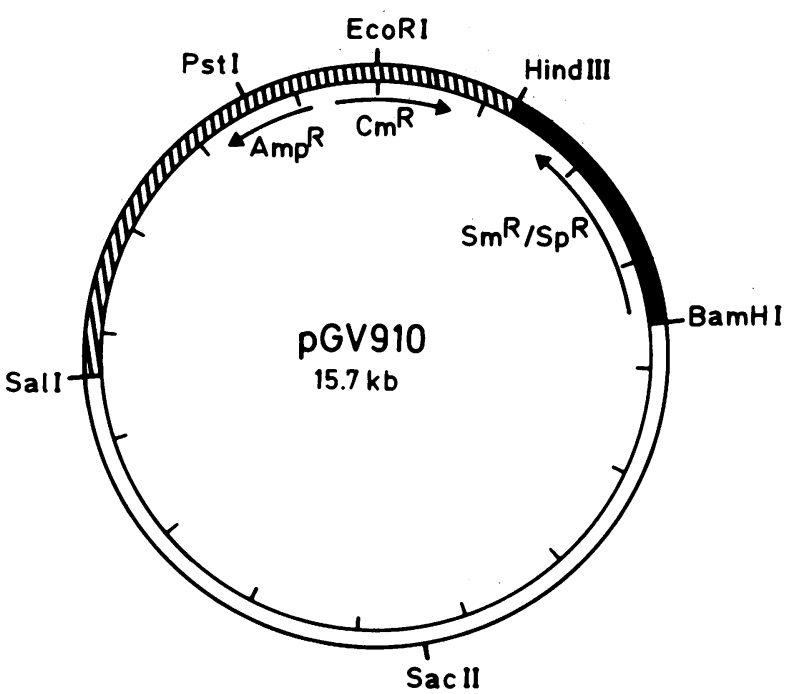

FIG. 1. Restriction map of the plasmid vector pGV910 (Van den Eede et al., unpublished data). Symbols: $\square$, R702 derived; $\square$, pVS1 derived; m $\mathrm{m}$, pBR325 derived. The indicated restriction sites are unique. The scale is in kilobases.

Agrobacterium background. Because of the negative results in the hybridization experiments, we switched to a functional approach based on a search for clones capable of activating in trans the expression of a reporter lac $Z$ fusion in the presence of the inducing flavanone naringenin. Because we did not have at our disposal the equivalent of a NodD ORS571 strain (such as, for instance, would be provided for Rhizobium strains by sym plasmid-cured derivatives), these experiments had to be carried out in a different bacterial background. For that purpose, Agrobacterium tumefaciens GV3101 (a Ti plasmid-cured C58C1 derivative) was chosen, since it has been shown previously (38) that $R$. meliloti nodDl can activate transcription of the common nod genes in an Agrobacterium background in the presence of alfalfa root exudate.

A further prerequisite for this approach was the ability to maintain two different plasmids in the same bacterium: one containing a reporter lac $Z$ fusion in a common nod gene and the other carrying a putative activator locus from ORS571. This could be achieved by combining two different wide-host-range plasmids: pRK290 (or the derived cosmid pLAFR1), selecting for tetracycline resistance, and pGV910, selecting for spectinomycin-streptomycin resistance. These plasmids are compatible and have approximately equal copy numbers (R. Deblaere, personal communication). Plasmid pGV910 is a derivative of pVS1 (21); its construction, features, and further applications are described elsewhere (G. Van den Eede et al., unpublished data), but for the sake of clarity a restriction map of pGV910 is given in Fig. 1.

A GV3101 derivative was constructed that harbors the pGV910-type plasmid pRG910-12::M3 carrying a lacZ gene fused to the common nodC gene of ORS571 (Fig. 2; see Materials and Methods). In this strain, no effect of naringenin on the expression of the nodC-lac $Z$ fusion M3 could be measured (Table 2, line 1). Into this strain, a partial EcoRI gene bank of ORS571 in the cosmid vector pLAFR1 was introduced via triparental mating. To identify pLAFR1 clones allowing naringenin-inducible expression of the reporter gene, $\mathrm{Tc}^{\mathrm{r}} \mathrm{Sp}^{\mathrm{r}}$ transconjugants were individually screened by spotting on MacConkey agar plates with and 


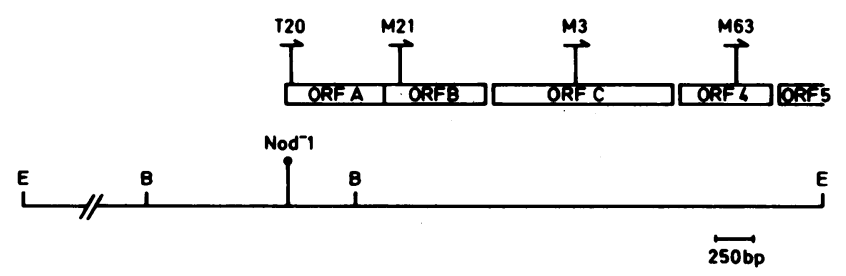

FIG. 2. Simplified restriction map of the 12.7-kb EcoRI fragment carrying the nod locus 1 of ORS571. Symbols: $i$, position of the nod-Tn 5 insertion originally defining the nod locus $1 ; \rightarrow$, positions and orientations of lacZ fusions T20, M21, M3, and M63. For details, see reference 14. Abbreviations for restriction enzymes: B, BamHI; E, EcoRI.

without $20 \mu \mathrm{M}$ naringenin. On this medium, colonies of the acceptor strain GV3101(pRG910-12::M3) were whitepinkish. Several hundred transconjugants were screened and found to be indistinguishable from the recipient strain except for one transconjugant that became bright red on the naringenin-containing medium.

From this transconjugant, the cosmid DNA (called pRG100) was isolated and transformed to $E$. coli MC1061 for further physical analysis. The pRG100 insert contained four EcoRI fragments of $16,11,1.5$, and $1 \mathrm{~kb}$, respectively. By subcloning, the 16-kb EcoRI fragment was found to be responsible for the transactivating capacity. For this subcloning and further characterizations, the putative activator loci were always cloned in the pGV910 vector so that they could be combined with the different nod locus 1 reporter fusions (Fig. 2) that were available in the pRK290-type vector (a situation opposite from the one used to identify the activating clone from the gene library).

A restriction map of the 16-kb EcoRI fragment was

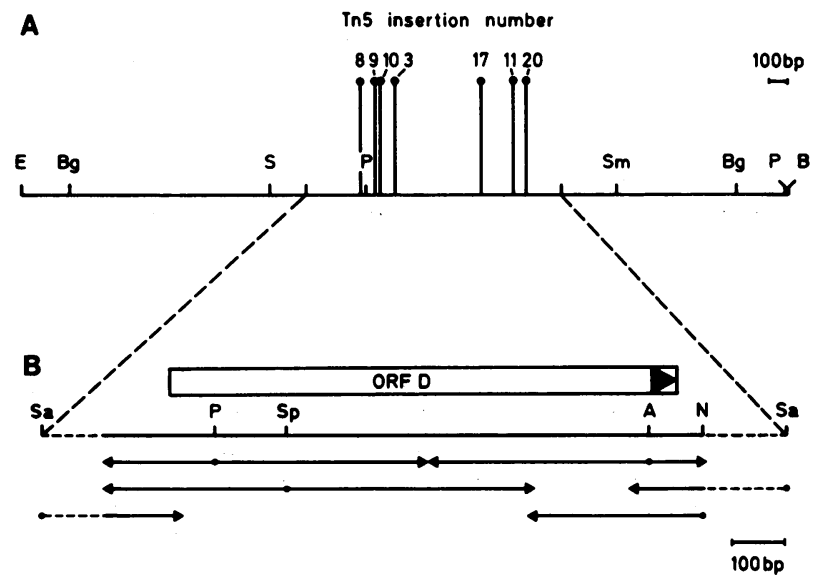

FIG. 3. Restriction map and sequencing strategy of nod locus 3 . (A) Restriction map of the 4-kb EcoRI-BamHI fragment carrying the nodD gene of ORS571. i , Positions of different Tn5 insertions abolishing ORFD activity. (B) Strategy for sequencing the 4-kb EcoRI-Bam HI fragment carrying ORFD. Arrows indicate directions and lengths of the sequences determined; the arrowhead indicates the orientation of ORFD. Abbreviations for restriction enzymes: A, AvaI; B, BglII; E, EcoRI; N, NruI; P, PstI; S, SalI; Sa, SauI; Sm, SmaI; Sp, SplI. Not necessarily all sites are indicated for each restriction enzyme.

constructed, and by further subcloning the activating function was allocated to a 4-kb EcoRI-BamHI fragment (Fig. 3).

Data presented in Table 2 (lines 1 to 7 ) illustrate the above-mentioned steps by quantitative measurements of the expression of the nodC-lacZ fusion M3 and the nodA-lacZ fusion T20. In the presence of the activator locus, a three- to fourfold increase in $\beta$-galactosidase units was observed $4 \mathrm{~h}$ after the addition of naringenin. Similar results (data not

TABLE 2. Quantitative $\beta$-galactosidase measurements of nod-lac $Z$ fusions in different backgrounds ${ }^{a}$

\begin{tabular}{|c|c|c|c|c|}
\hline \multirow[t]{2}{*}{ Strain } & \multirow[t]{2}{*}{ Reporter plasmid } & \multirow[t]{2}{*}{ Activator plasmid } & \multicolumn{2}{|c|}{$\begin{array}{l}\beta \text {-Galactosidase activity } \\
\text { (U) }\end{array}$} \\
\hline & & & $-\mathrm{Nar}$ & $+\mathrm{Nar}$ \\
\hline \multicolumn{5}{|l|}{ Agrobacterium tumefaciens } \\
\hline 1. GV3101 & pRG910-12::M3 (nodC-lacZ) & & 49 & 50 \\
\hline 2. GV3101 & pRG910-12::M3 & pRG100 & 63 & 145 \\
\hline 3. GV3101 & pRG290-12::M3 & & 52 & 53 \\
\hline 4. GV3101 & pRG290-12::M3 & pRG910-16 & 47 & 113 \\
\hline 5. GV3101 & pRG290-12::T20 (nodA-lacZ) & & 45 & 47 \\
\hline 6. GV3101 & pRG290-12::T20 & pRG910-16 & 40 & 180 \\
\hline 7. GV3101 & pRG290-12::T20 & pRG910-4 & 58 & 220 \\
\hline 8. GV3101 & pRG290-12::T20 & pRG910-16::Tn5-3 & 39 & 43 \\
\hline \multicolumn{5}{|l|}{ Escherichia coli } \\
\hline 9. MC1061 & pRG290-12::T20 & & 51 & 50 \\
\hline 10. MC1061 & pRG290-12::T20 & pRG910-4 & 70 & 64 \\
\hline \multicolumn{5}{|l|}{ Azorhizobium caulinodans } \\
\hline 11. ORS571 (wild-type) & pRG290-12::T20 & & 27 & 1,081 \\
\hline 12. ORS571-S (spontaneous mutant) & pRG290-12::T20 & & 17 & 17 \\
\hline 13. ORS571-S & pRG290-12::T20 & pRG910-16 & 21 & 1,209 \\
\hline 14. ORS571-S & pRG290-12::T20 & pRG910-4 & 90 & 1,548 \\
\hline 15. ORS571-S & pRG290-12::T20 & pRG910-16::Tn5-3 & 10 & 10 \\
\hline 16. ORS571-3 (homogenote Tn5-3) & pRG290-12::T20 & & 16 & 16 \\
\hline 17. ORS571-3 & pRG290-12::T20 & pRG910-16 & 47 & 1,320 \\
\hline 18. ORS571-3 & pRG290-12::T20 & pRG910-4 & 92 & 1,375 \\
\hline
\end{tabular}

${ }^{a}$ The $\beta$-galactosidase assays were carried out as described previously (14). For Agrobacterium tumefaciens and $E$. coli, lac $Z$ activity was measured $4 \mathrm{~h}$ after induction with $20 \mu \mathrm{M}$ naringenin (Nar); A. caulinodans fusions were measured after $12 \mathrm{~h}$ of induction with $10 \mu \mathrm{M}$ naringenin. Media were as described in Materials and Methods. Background levels of lacZ activity were less than 5 U in GV3101, MC1061, and ORS571. 


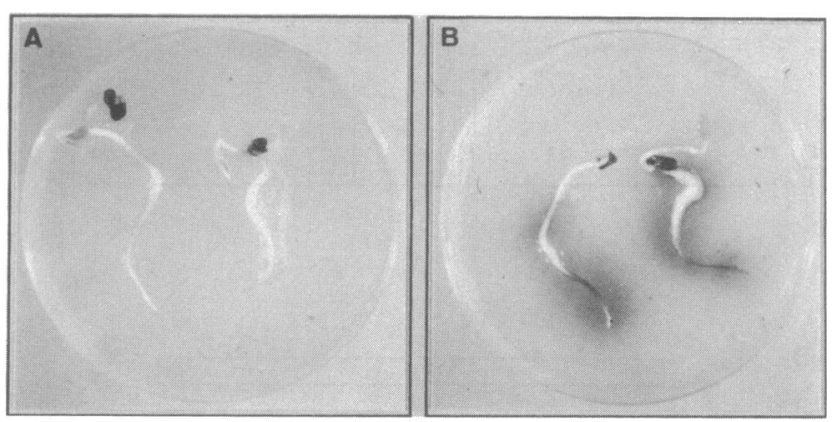

FIG. 4. In vivo assay for nod gene induction in Agrobacterium strain GV3101. On PA plates containing X-Gal $(80 \mu \mathrm{g} / \mathrm{ml})$ and a lawn of a GV3101 derivative, sterile seedlings of $S$. rostrata were incubated in the dark at $28^{\circ} \mathrm{C}$ for $12 \mathrm{~h}$. (A) GV3101(pRG290-12::T20); (B) GV3101(pRG290-12::T20, pRG910-4).

shown) in Agrobacterium sp. were obtained with lacZ fusions in nodB (M21) and ORF4 (M63) (Fig. 2). In an E. coli MC1061 background, no such induction could be obtained. Inducing factors exuded by $S$. rostrata likewise enhanced the expression in Agrobacterium sp. of nod locus 1 gene fusions if an activator locus was present (Fig. 4).

Isolation of a spontaneous noninducible ORS571 mutation complementable by pRG910-16. While characterization of the ORS571 activator locus in Agrobacterium sp. was in progress, we isolated a spontaneous ORS571 mutant (ORS571-S) that had lost the ability to activate nod locus 1 genes in the presence of naringenin or host plant exudate. This mutant was isolated starting from an ORS571 derivative containing a pBR325 replicon-based reporter plasmid pRG701::M63 (Table 1) cointegrated in the genome. When this strain was plated on a medium containing naringenin, X-Gal, and tetracycline, colonies turned dark blue because of the induced expression of the ORF4-lacZ fusion M63. A pale blue colony was detected that, upon further investigation, was found to harbor a chromosomally located mutation affecting the expression of the nod locus 1 genes.

Indeed, after excision and subsequent loss of the pRG701:: M63 plasmid, a $\mathrm{Tc}^{\mathrm{s}}$ derivative strain resulted (ORS571-S) into which reporter plasmids with $l a c Z$ fusions in ORFA, ORFB, ORFC, or ORF4 were introduced. In all of the resulting strains, expression of the lacZ fusion could be induced neither by naringenin nor by host plant exudate. The mutant ORS571-S could be phenotypically complemented by introducing plasmid pRG910-16 or pRG910-4 (Table 1). Expression of the ORFA-lacZ fusion T20 in wild-type ORS571, in ORS571-S, in ORS571-S(pRG910-16), and in ORS571-S(pRG910-4) is presented in Table 2 (lines 11 to 14).

The spontaneous mutant ORS571-S was used as a recipient strain to delimit the activator locus by $\operatorname{Tn} 5$ insertion mutagenesis.

Tn5 mutagenesis of pRG910-16 to delimit the activator locus. Plasmid pRG910-16 encodes one or more functions involved in transactivation of the expression of nod locus 1 gene fusions in Agrobacterium sp. and is capable of complementing the spontaneous noninducible mutant ORS571-S.

A population of $\mathrm{pRG910-16}$ derivatives harboring a Tn5 insertion was generated in E. coli MC1061 (see Materials and Methods; 7). The mutated plasmids were introduced into strain ORS571-S(pRG290-12::T20) by triparental mating, and transconjugants were selected and simultaneously screened by plating on minimal medium (MMO) with X-Gal $(40 \mu \mathrm{g} / \mathrm{ml})$, spectinomycin $(20 \mu \mathrm{g} / \mathrm{ml})$, tetracycline $(10 \mu \mathrm{g} /$ $\mathrm{ml})$, and naringenin $(10 \mu \mathrm{M})$. Colonies that remained pale blue on this medium (indicating possible absence of complementation) were isolated; plasmid DNA was prepared and transformed to $E$. coli MC1061, with selection for the pRG910-16::Tn5 markers (spectinomycin and kanamycin). The position of the $\operatorname{Tn} 5$ insertion in each plasmid was determined via restriction mapping (Fig. 3).

The different Tn 5 insertions delimit a DNA stretch of approximately $0.8 \mathrm{~kb}$ that is essential for the transactivation of nod gene expression in the presence of the inducer. This conclusion was confirmed by introducing the individual mutant plasmids in strain GV3101(pRG290-12::T20), leading to transconjugants that were unable to induce $\beta$-galactosidase expression in the presence of naringenin or host plant exudate (Table 2 , line 8 ).

Sequence of the activator locus. Using a modified MaxamGilbert procedure (see Materials and Methods), 1,110 nucleotides of the regulatory locus carried by the pRG910-4 insert and delimited by the Tn5 insertion mutagenesis were sequenced (Fig. 3). Analysis of the sequence revealed a 942-base-pair (bp)-long ORF (ORFD) (Fig. 5), the location of which coincides with the mapped positions of the different $\mathrm{Tn} 5$ insertions that inactivate the trans-acting regulatory function of pRG910-4 (Fig. 3).

Computer-assisted analysis of the sequence revealed that the nucleotide sequence as well as the deduced amino acid sequence of ORFD show significant homology with the corresponding sequences of (brady)rhizobial nodD genes. At the nucleotide level, the overall homology, comparing ORFD with $R$. meliloti nodD 1 and MPIK3030 nodD, adds up to 52 and $48 \%$, respectively. In the protein sequence, about $51 \%$ of the amino acids are either identical residues $(32 \%)$ or conservative substitutions compared with the sequence of eight other NodD proteins (Fig. 5). Long stretches of conserved residues are found in the amino-terminal half, whereas the rest of the protein shows a more dispersed type of conservation. The most proximally located conserved stretch encompasses 19 amino acids containing 13 identical residues and six conservative substitutions, one of which is a TTG-encoded leucine residue at position 1 (position 127 in the nucleotide sequence), which corresponds to the presumed methionine start residue of all other NodD proteins. Moreover, immediately upstream from this TTG codon are an in-frame stop codon and a strongly conserved ShineDalgarno sequence (33) (Fig. 5). These observations suggest that the TTG codon is the actual methionine start codon of the ORFD gene product.

ORFD ends at nucleotide 1079 with a TAG stop codon and as such encodes a 314-amino-acid polypeptide with a molecular mass of 35,565 daltons, a size comparable to that of other NodD proteins. By sequencing some 1,000 nucleotides downstream from ORFD (data not shown), no evidence was found for the presence of a large, cotranscribed ORF.

Analysis of the ORFD 126-bp upstream sequence revealed the presence of a divergently oriented nod box-related sequence (Fig. 5). This nod box is positioned relative to the TTG start codon very similarly to the nod box-nodD organization found in (brady)rhizobia $(19,30)$.

Genomic hybridization using ORFD as a probe. To find out whether ORFD is a unique gene or whether cryptic nodD sequences are present in the ORS571 genome, we carried out genomic hybridizations. Southern blots of EcoRI-, HindIII-, or BamHI-digested total DNA of ORS571 were prepared and used in low-stringency hybridization experiments (see Materials and Methods). As a radioactive probe, the 896-bp PstI-SacI fragment (the DNA spanning nucleotides 204 to 
1 TCGTGCAGAGATACCATGCGCTGTGCGCCTACAGCGAAGCAAGATGTGACGCTGGACAATCTTTCGTAGCT

139

193

247

301

355

409

463

517

571

625

679

733

787

841

895

949

1003 TAC CTA GCG GAC CAT ACA TCC CAA ATC ATG ATT TTG GAC AGC GCA GAA TAT TCG Tyr Leu Ala Asp His Thr Ser Gln MET MET I le Leu Asp Ser Ala Glu Tyr Ser

1057 GGA GCT TCC ATA TAG TCGTTTTCCGATATGCAGAGATCAaGAGCTCTCAATCGC

Gly Ala Ser Ile *

FIG. 5. Sequence of ORFD (nod locus 3) of strain ORS571. The sequence of a 1,110-bp fragment is shown. Underlined bases indicate the Shine-Dalgarno-like sequences. The stop codon is indicated by an asterisk. The predicted amino acid sequence of the ORFD gene product is given in three-letter code under the nucleotide sequence. Shaded amino acids are those that are identical (boxed) or similar in the published sequences of $R$. meliloti 41 nodDI and nodD2 (16), Rhizobium leguminosarum biovar viciae and biovar trifolii nodD (29, 31), Bradyrhizobium parasponiae nodDI (30), Rhizobium strain MPIK3030 nodDl (19), and Rhizobium japonicum nodD1 and nodD2 (3). Similar residues are those belonging to the groups DEQN, AGST, VLIM, KR, and WYF (one-letter code). The bases upstream from the TTG translational start codon that constitute a divergently oriented nod box-like sequence are boxed.

1101 in Fig. 5) was used. Upon exposure, a single hybridizing band became apparent in all cases tested, consistent with ORFD being present as a unique gene in ORS571 (Fig. 6). Exactly the same pattern of hybridization was visible with total DNA prepared from the mutant ORS571-S (data not shown), indicating the absence of large deletions or rearrangements in the ORFD region of this strain.

Symbiotic phenotype of an ORFD::Tn5 homogenote and of the spontaneous mutant ORS571-S. A Tn5 insertion (Tn5-3; Fig. 3) in ORFD was chosen for homogenotization in the ORS571 genome in order to study the effect of the inactivation of this gene on the symbiotic properties of the strain. A homogenote, ORS571-3, was isolated and characterized as described in Materials and Methods. When ORS571-3 was used in a triparental mating as an acceptor strain for nod locus 1 -lac $Z$ reporter plasmids, the resulting transconjugants

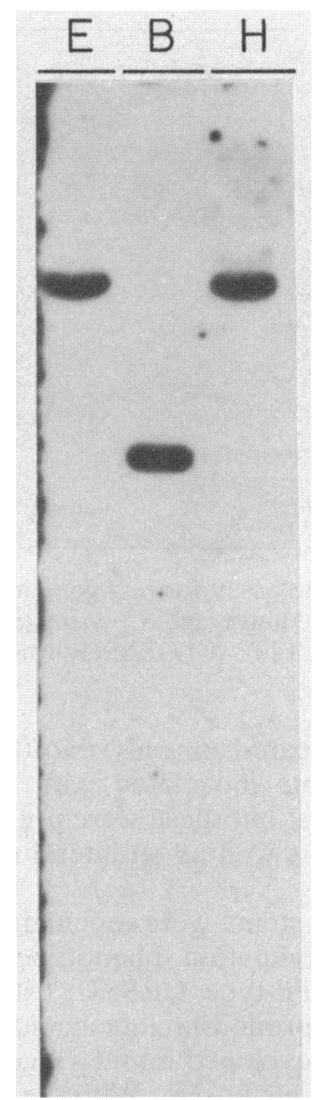

FIG. 6. Radiogram obtained after hybridization of Southernblotted ORS571 genomic DNA to an ORFD specific probe (see text). The DNA was digested with EcoRI (lane E), HindIII (lane H), and BamHI (lane B).

were unable to induce lac $Z$ expression either by naringenin or in the presence of $S$. rostrata exudate (Table 2, line 16; Fig. 7). As expected, the noninducible phenotype was complemented by the introduction of either pRG910-16 or pRG910-4 carrying the wild-type nodD locus (Table 2, lines 17 and 18; Fig. 7).

Strain ORS571-3 was tested for its symbiotic phenotype by inoculation on $S$. rostrata roots and stems (Fig. 8). In neither case could nodules be obtained. Root inoculations occasionally yielded a few, very delayed-appearing nodules. Bacteria isolated from these nodules were ORS571 according to growth behavior, colony morphology, and the high level of carbenicillin resistance, but they had lost the Tn5encoded kanamycin resistance marker. Upon reinoculation, these bacteria showed a normal nodulation behavior; by these criteria, we presume that the exceptional root nodules were due to the occurrence of rare revertants that had lost the Tn 5 insertion by excision. It can be concluded that inactivation of ORFD by $\mathrm{Tn} 5$ insertion leads to a complete $\mathrm{Nod}^{-}$phenotype on $S$. rostrata roots and stems. Introduction of pRG910-4 in the NodD ${ }^{-}$mutant ORS571-3 restored the nodulation capacity on roots as well as stems.

The spontaneous mutant ORS571-S, undistinguishable from the homogenote ORS571-3 with respect to absence of plant-inducible common nod gene expression, nevertheless differed in its nodulation phenotype: instead of being $\mathrm{Nod}^{-}$, it showed delayed stem and root nodulation. Five days after inoculations, wild-type ORS571 yielded small nodules on all inoculated roots, whereas with the mutant ORS571-S, a few 

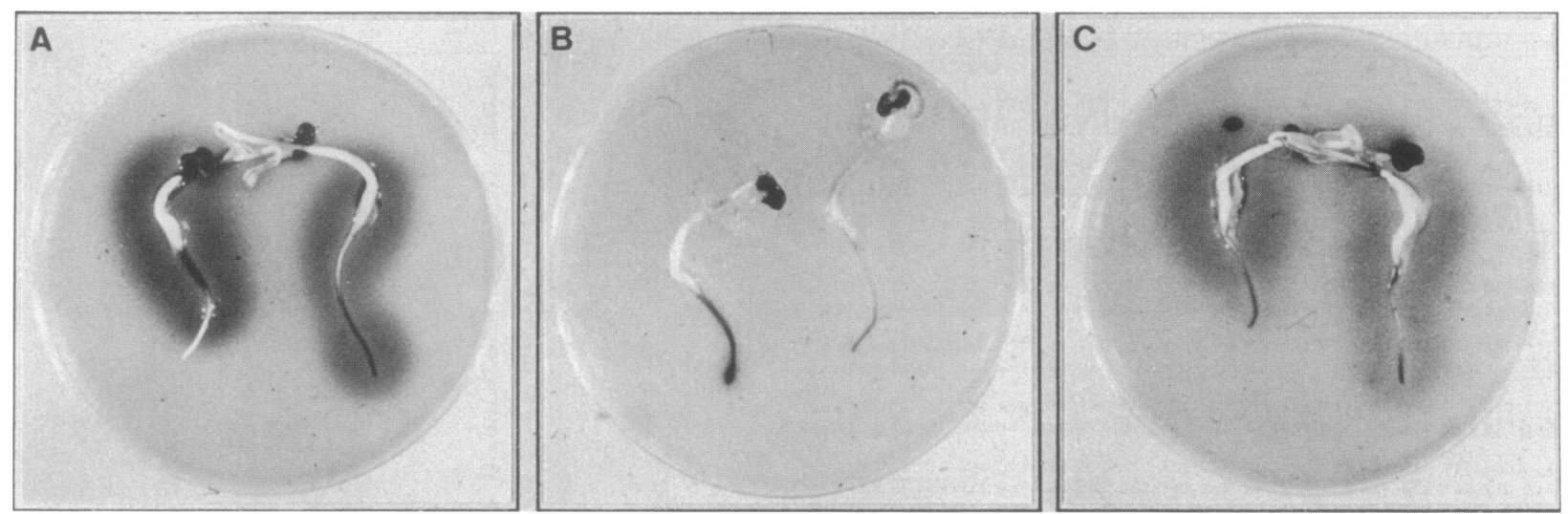

FIG. 7. In vivo plate assay for nod gene induction in ORS571. On MMO plates containing X-Gal (80 $\mu \mathrm{g} / \mathrm{ml})$ and a lawn of an ORS571 derivative, sterile seedlings of $S$. rostrata were incubated in the dark at $37^{\circ} \mathrm{C}$ for $12 \mathrm{~h}$. (A) ORS571(pRG290-12::T20); (B) ORS571-3(pRG290-12::T20); (C) ORS571-3(pRG290-12::T20, pRG910-4).

small swellings appeared on only two-thirds of the inoculated roots. All roots inoculated with ORS571-S showed nodules after 10 days, but these were present on lower parts of the root system as well as on lateral roots and they had very irregular sizes.

When $S$. rostrata stems were inoculated with ORS571-S, again a delayed nodulation phenotype was apparent in comparison with wild-type ORS571. After 10 days, most infection sites (root primordia) inoculated with the wild-type strain had already developed into dark-green, beadlike nodules very homogeneous in size. With the ORS571-S mutant, far fewer infection sites developed into nodules, and the nodules that appeared were very heterogeneous in size, either remaining very small or growing abnormally large (Fig. 8).

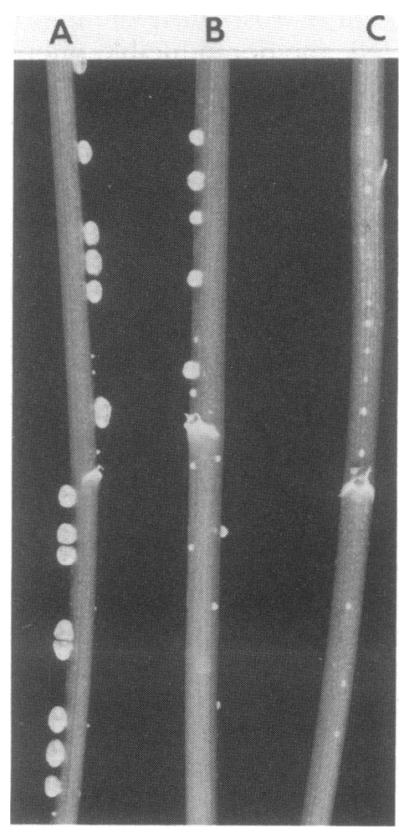

FIG. 8. Stem nodulation with ORS571 derivatives. Tests were done as described previously (34). Shown are sections of the stem 10 days after infection with the indicated strain. (A) Wild-type ORS571; (B) ORS571-S; (C) ORS571-3.

\section{DISCUSSION}

The (brady)rhizobial nodD genes play a central role in the flavonoid-induced expression of the nod regulon. In a previous report, we documented the presence of a flavonoidregulated common nod operon in A. caulinodans ORS571 (nod locus $1 ; 14$ ). Upstream from this operon, no nodD-like gene was present. Furthermore, hybridization experiments with ORS571 total DNA using the $R$. meliloti nodDl gene or the NGR234 nodD1 gene as a probe did not allow us to detect related sequences in the ORS571 genome. Here, we described the isolation by a functional approach of an ORS571 activator gene which, by several criteria, can be considered a nodD gene.

The activator locus was isolated from an ORS571 gene bank by screening for transactivation of an Azorhizobium nodC-lacZ fusion in an Agrobacterium background and in the presence of the inducer naringenin. Subcloning of the locus delimited its location to a \pm 4 -kb EcoRI-BamHI fragment, and by $\operatorname{Tn} 5$ mutagenesis the regulatory function was further delimited to a $0.8-\mathrm{kb}$ fragment. Homogenotization in the ORS571 genome of a Tn5 insertion in the activator region resulted in a mutant strain, ORS571-3, that was unable to induce the expression of common nod-lac $Z$ fusions in the presence of $S$. rostrata exudate or the inducing flavanone naringenin and unable to elicit nodules on the roots or the stems of $S$. rostrata. Both mutant phenotypes were complemented upon introduction of a clone carrying the wild-type activator locus. These data together with the results of hybridization experiments indicate the presence in ORS571 of a unique nodD-like regulatory gene (nod locus 3 ). There is no evidence for a close linkage between the activator locus and nod locus 1 or 2 (34).

Further confirmation of the nodD-like character of the activator gene was found by DNA sequence analysis. A single, 942-bp-long ORF is present (ORFD) which encodes a 35,565-dalton protein. At the nucleotide level, ORFD shows some $50 \%$ homology with several published nodD genes. Although this level of similarity is significant, it is the lowest observed thus far for this gene family. Therefore, it seems that in Azorhizobium spp. the nodD gene is evolutionary more divergent, a situation also reflected in the low degree of conservation exhibited by the common nod genes (14). At the protein level, the overall amino acid identity between the putative ORFD gene product and eight other NodD proteins 
adds up to $32 \%$. The highest level of homology was found in the amino-terminal part of the protein, possibly containing a helix-turn-helix domain involved in the binding of DNA.

Translation of ORFD most probably starts at a TTG initiation codon. There are several arguments that support this unusual situation. The strong amino-terminal homology between the ORFD-derived protein and all other tested NodD proteins places the methionine start codon of the latter at precisely the position of this TTG codon in the former. Furthermore, immediately upstream from the TTG codon is an in-frame stop codon. Finally, at the appropriate position upstream from the presumed TTG start codon, a well-conserved Shine-Dalgarno sequence is located. The use of this alternative start codon has been reported in only a few exceptional cases (15). Interestingly, one example is the regulatory virG gene of Agrobacterium rhizogenes and possibly Agrobacterium tumefaciens (2). Perhaps this situation reflects a kind of translational control involved in the synthesis of optimal concentrations of these regulatory proteins. Immediately upstream from the ORS571 nodD gene is a divergently oriented nod box-related sequence, the function of which is unknown. A nod box with the same relative orientation and position was also found upstream from several other nodD genes (19).

In this report we have also described the isolation of a spontaneous ORS571 mutant (ORS571-S) with the same noninducible phenotype as the NodD $^{-}$Tn5 homogenote ORS571-3 but with a different nodulation phenotype. The spontaneous mutant was not completely $\mathrm{Nod}^{-}$but showed delayed stem and root nodulation. The aberrant nodulation as well as the absence of plant-inducible common nod gene expression were complemented upon introduction in ORS571-S of a clone carrying the wild-type nodD locus. When such a clone carried a Tn5 insertion in ORFD, no complementation occurred. These genetic data indicate that the spontaneous mutation may be located in the nodD gene. Possibly the defective phenotype of ORS571-S is a result of a point mutation in ORFD or its promoter, since no major rearrangements or deletions in the ORFD region were evident upon hybridization analysis, although the presence of a small deletion or rearrangement cannot be excluded for the moment. From sequencing data, we know that ORFD is not followed by another cotranscribed gene; therefore, the difference in nodulation behavior between ORS571-3 and ORS571-S cannot be explained by a polar effect of the Tn5 insertion on expression of a downstream gene involved in nodulation. A possible explanation that is worth investigating is that whereas in ORS571-3 the nodD function is completely abolished by $\mathrm{Tn} 5$ insertion, in ORS571-S the mutation affects only part of the function (inducible activation) of the regulatory protein but leaves intact another function that contributes in an as yet unknown way to nodulation.

\section{ACKNOWLEDGMENTS}

We thank J. Okamuro, D. Inzé, and J. Desomer for critical reading of the manuscript. We also thank Martine De Cock for typing the manuscript, Karel Spruyt, Stefaan Van Gijsegem and Vera Vermaercke for preparing the figures, and Lynn De Wijnter, Jan Gielen, and Claudine Maertens for excellent technical help.

This work was supported by grants from the Services of the Prime Minister (UIAP 12OC0187), the Commission of the European Communities (TS2-0135-B), the Vlaams Ontwikkelingsfonds, and the Ministerie voor Vlaamse Gemeenschap and by a NATO collaborative research grant. M.H. is a research associate of the National Fund for Scientific Research (Belgium).

\section{LITERATURE CITED}

1. Anderson, M. L. M., and B. D. Young. 1985. Quantitative filter hybridisation, p. 73-111. In B. D. Hames and S. J. Higgins (ed.), Nucleic acid hybridisation-a practical approach. IRL Press, Oxford.

2. Aoyama, T., T. Hirayama, S. Tamamoto, and A. Oka. 1989. Putative start codon TTG for the regulatory protein VirG of the hairy-root-inducing plasmid pRiA4. Gene 78:173-178.

3. Appelbaum, E. R., D. V. Thompson, K. Idler, and N. Chartrain. 1988. Rhizobium japonicum USDA 191 has two nodD genes that differ in primary structure and function. J. Bacteriol. 170:12-20.

4. Bolivar, F. 1978. Construction and characterization of new cloning vehicles. III. Derivatives of plasmid pBR322 carrying unique EcoRI sites for selection of EcoRI generated recombinant DNA molecules. Gene 4:121-136.

5. Burn, J., L. Rossen, and A. W. B. Johnston. 1987. Four classes of mutations in the nodD gene of Rhizobium leguminosarum biovar viciae that affect its ability to autoregulate and/or activate other nod genes in the presence of flavonoid inducers. Genes Dev. 1:456-464.

6. Casadaban, M. J., and S. N. Cohen. 1980. Analysis of gene control signals by DNA fusion and cloning in Escherichia coli. J. Mol. Biol. 138:179-207.

7. De Bruijn, F. J., and J. R. Lupski. 1984. The use of transposon Tn5 mutagenesis in the rapid generation of correlated physical and genetic maps of DNA segments cloned into multicopy plasmids-a review. Gene 27:131-149.

8. Ditta, G., S. Stanfield, D. Corbin, and D. R. Helinski. 1980. Broad host range DNA cloning system for Gram-negative bacteria: construction of a gene bank of Rhizobium meliloti. Proc. Natl. Acad. Sci. USA 77:7347-7351.

9. Dreyfus, B., D. Alazard, and Y. R. Dommergues. 1984. Stemnodulating Rhizobia, p. 161-169. In M. G. Klug and C. E. Reddy (ed.), Current perspectives on microbial ecology. American Society for Microbiology, Washington, D.C.

10. Dreyfus, B., and Y. R. Dommergues. 1981. Nitrogen fixing nodules induced by Rhizobium on the stem of the tropical legume Sesbania rostrata. FEMS Microbiol. Lett. 10:313-317.

11. Dreyfus, B., J. L. Garcia, and M. Gillis. 1988. Characterization of Azorhizobium caulinodans gen. nov., sp. nov., a stemnodulating nitrogen-fixing bacterium isolated from Sesbania rostrata. Int. J. Syst. Bacteriol. 38:89-98.

12. Fisher, R. F., T. T. Egelhoff, J. T. Mulligan, and S. R. Long. 1988. Specific binding of proteins from Rhizobium meliloti cell-free extracts containing NodD to DNA sequences upstream of inducible nodulation genes. Genes Dev. 2:282-293.

13. Friedman, A. M., S. R. Long, S. E. Brown, W. J. Buikema, and F. M. Ausubel. 1982. Construction of a broad host range cosmid cloning vector and its use in the genetic analysis of Rhizobium mutants. Gene 18:289-296.

14. Goethals, K., M. Gao, K. Tomekpe, M. Van Montagu, and M. Holsters. 1989. Common nodABC genes in Nod locus 1 of Azorhizobium caulinodans: nucleotide sequence and plant-inducible expression. Mol. Gen. Genet. 219:289-298.

15. Gold, L. 1988. Posttranscriptional regulatory mechanisms in Escherichia coli. Annu. Rev. Biochem. 57:199-233.

16. Göttfert, M., B. Horvath, E. Kondorosi, P. Putnoky, F. Rodriguez-Quinones, and A. Kondorosi. 1986. At least two nodD genes are necessary for efficient nodulation of alfalfa by Rhizobium meliloti. J. Mol. Biol. 191:411-420.

17. Heffron, F., P. Bedinger, J. J. Champoux, and S. Falkow. 1977. Deletions affecting the transposition of an antibiotic resistance gene. Proc. Natl. Acad. Sci. USA 74:702-706.

18. Henikofi, S., G. W. Haughn, J. M. Calvo, and J. C. Wallace. 1988. A large family of bacterial activator proteins. Proc. Natl. Acad. Sci. USA 85:6602-6606.

19. Horvath, B., C. W. B. Bachem, J. Schell, and A. Kondorosi. 1987. Host-specific regulation of nodulation genes in Rhizobium is mediated by a plant-signal, interacting with the nodD gene product. EMBO J. 6:841-848.

20. Huey, B., and J. Hall. 1989. Hypervariable DNA fingerprinting in Escherichia coli: minisatellite probe from bacteriophage M13. J. Bacteriol. 171:2528-2532. 
21. Itoh, Y., J. M. Watson, D. Haas, and T. Leisinger. 1984. Genetic and molecular characterization of the Pseudomonas plasmid pVS1. Plasmid 11:206-220.

22. Kondorosi, E., J. Gyuris, J. Schmidt, M. John, E. Duda, B. Hoffmann, J. Schell, and A. Kondorosi. 1989. Positive and negative control of nod gene expression in Rhizobium meliloti is required for optimal nodulation. EMBO J. 8:1331-1340.

23. Long, S. R. 1989. Rhizobium-legume nodulation: life together in the underground. Cell 56:203-214.

24. Maniatis, T., E. F. Fritsch, and J. Sambrook. 1982. Molecular cloning: a laboratory manual. Cold Spring Harbor Laboratory, Cold Spring Harbor, N.Y.

25. Miller, J. H. 1972. Experiments in molecular genetics. Cold Spring Harbor Laboratory, Cold Spring Harbor, N.Y.

26. Rolfe, B. G., and P. M. Gresshoff. 1988. Genetic analysis of legume nodule initiation. Annu. Rev. Plant Physiol. Plant Mol. Biol. 39:297-319.

27. Rostas, K., E. Kondorosi, B. Horvath, A. Simoncsits, and A. Kondorosi. 1986. Conservation of extended promoter regions of nodulation genes in Rhizobium. Proc. Natl. Acad. Sci. USA 83:1757-1761.

28. Ryskov, A. P., A. G. Jincharadze, M. I. Prosnyak, P. L. Ivanov, and S. A. Limborska. 1988. M13 phage DNA as a universal marker for DNA fingerprinting of animals, plants and microorganisms. FEBS Lett. 233:388-392.

29. Schofield, P. R., and J. M. Watson. 1986. DNA sequence of Rhizobium trifolii nodulation genes reveals a reiterated and potentially regulatory sequence preceding nodABC and nodFE. Nucleic Acids Res. 14:2891-2903.

30. Scott, K. F. 1986. Conserved nodulation genes from the nonlegume symbiont Bradyrhizobium sp. (Parasponia). Nucleic
Acids Res. 14:2905-2919.

31. Shearman, C. A., L. Rossen, A. W. B. Johnston, and J. A. Downie. 1986. The Rhizobium leguminosarum nodulation gene $n o d F$ encodes a polypeptide similar to acyl-carrier protein and is regulated by nodD plus a factor in pea root exudate. EMBO J. 5:647-652.

32. Spaink, H. P., C. A. Wijffelman, E. Pees, R. J. H. Okker, and B. J. J. Lugtenberg. 1987. Rhizobium nodulation gene nodD as a determinant of host specificity. Nature (London) 328:337-340.

33. Stormo, G. D., T. D. Schneider, and L. M. Gold. 1982. Characterization of translational initiation sites in E. coli. Nucleic Acids Res. 10:2971-2996.

34. Van den Eede, G., B. Dreyfus, K. Goethals, M. Van Montagu, and M. Holsters. 1987. Identification and cloning of nodulation genes from the stem-nodulating bacterium ORS571. Mol. Gen. Genet. 206:291-299.

35. Van Larebeke, N., G. Engler, M. Holsters, S. Van den Elsacker, I. Zaenen, R. A. Schilperoort, and J. Schell. 1974. Large plasmid in Agrobacterium tumefaciens essential for crown gall-inducing ability. Nature (London) 252:169-170.

36. Vervliet, G., M. Holsters, H. Teuchy, M. Van Montagu, and J. Schell. 1975. Characterization of different plaque-forming and defective temperate phages in Agrobacterium strains. J. Gen. Virol. 26:33-48.

37. Vieira, J., and J. Messing. 1982. The pUC plasmids, an M13mp7-derived system for insertion mutagenesis and sequencing with synthetic universal primers. Gene 19:259-268.

38. Yelton, M. M., J. T. Mulligan, and S. R. Long. 1987. Expression of Rhizobium meliloti nod genes in Rhizobium and Agrobacterium backgrounds. J. Bacteriol. 169:3094-3098. 